\title{
Paideusis
}

\section{Better Schools: A Values Perspective (Clive Beck)}

\section{Walter C. Okshevsky}

Volume 4, Number 2, 1991

URI: https://id.erudit.org/iderudit/1073386ar

DOI: https://doi.org/10.7202/1073386ar

See table of contents

Publisher(s)

Canadian Philosophy of Education Society

ISSN

0838-4517 (print)

1916-0348 (digital)

Explore this journal

Cite this review

Okshevsky, W. (1991). Review of [Better Schools: A Values Perspective (Clive Beck)]. Paideusis, 4(2), 46-48. https://doi.org/10.7202/1073386ar

This document is protected by copyright law. Use of the services of Erudit (including reproduction) is subject to its terms and conditions, which can be viewed online.

https://apropos.erudit.org/en/users/policy-on-use/
This article is disseminated and preserved by Érudit.

Érudit is a non-profit inter-university consortium of the Université de Montréal, Université Laval, and the Université du Québec à Montréal. Its mission is to promote and disseminate research.

https://www.erudit.org/en/ 
tion via history, philosophy, sociology and psychology, the articles are for the most part good ones, and it is handy to have one volume which offers quick reference to a bit of everything. This is something like having a convenience store down the block: you can nip in at any time and know you will find an item or two from each of the food groups. However, if you're really interested in a good selection of fresh vegetables or baked goods, you are likely to go to a specialty store.

Given a more narrow focus, some of these articles might have been combined more successfully. For instance, there are chapters on teaching in two different sections of the book covering teacher education, instructional psychology and teaching, and the authority, rights and obligations of teachers. A smaller volume, looking specifically at teaching through different disciplines might have effectively combined these articles and several others. But here the cumulative effect of reflecting on teaching is somewhat lost because the articles are separated and because there is so much else to reflect on. Looking at the different topics in the book through one discipline, or looking at one topic through several disciplines would have been more useful. We have in this book different disciplines and different topics, and the result is a collection useful as a set of references but too broad to have real coherence.

As the purposes of these two books are somewhat different, they are not really comparable, but as a collection, measured against the criteria listed earlier, the Hare and Portelli book is the more successful.

Reviewed by Deborah Court

Clive Beck, Better Schools: A Values Perspective (New York: The Falmer Press, 1990).

At a time when "the starry heavens above" are easily mistaken for antiaircraft and missile fire, I read Professor Beck's recent book as one which exhorts us to look again at "the moral order within" -- specifically within the embodiments of ourselves that are our schools and society -- and to ask whether we, as teachers, philosophers, administrators, and parents, are not also mistaking the ultimate purposes of our educational acts. Better Schools is a very clearly thought-out and elegantly written book by an accomplished philosopher and writer who has devoted decades to the study of its topics and concerns. I believe the book will, or at least should, become a standard text and reference for a wide variety of issues, and a wide range of graduate and under-graduate courses, within the areas of "Foundations," "Administration," and "Curriculum Studies."

The book asks and addresses two fundamental questions. First, if we are not to myopically view the teaching of concepts, skills, and values as if these were ends in themselves, then what ultimately should we take the genuine goals of schooling to be? Second, what is to be the actual form and means which the direction of educational reform requires if we are to realize these goals? Both questions are motivated by and consistently address Beck's two-fold assessment of the present performance of schools. On the one hand, Beck contends that "the performance of schools might well be described as scandalous. ... 
[S]chools massively deprive children of intellectual and cultural stimulation, teaching with a scope and efficiency considerably less than what is needed; and secondly, schools enormously distort children's perceptions of social and political reality and of what is ultimately important in life"(viii). Such criticism, however, is not another instance of the kind of teacher-/curriculum-/schoolbashing to which we have grown inured in educational theory. For in keeping with and exemplifying its own professed "values-perspective," Beck's analyses and recommendations consistently proceed within an explicit awareness of the fact that schools are themselves conditioned by and reflect concrete social, cultural, and political factors which act as co-agents in the task of educational reform and which simultaneously set limits on the possibilities for such reform. Hence, tempering the above assessment is the recognition that the causes of this scandal are not solely or even primarily attributable to the school itself as some decontextualized, abstract entity. The scandal of contemporary schooling "is largely a societal one; and a broad societal effort is required with the school as just one of several players" (viii). From this perspective of hard realism, Beck claims our assessments need to also acknowledge that "[s]chools are doing quite well under the circumstances" (viii).

What is perhaps most valuable about this book, given our times, and what I believe teachers and other "front-line" practitioners in education will immediately take to and appreciate as an articulation and development of their own personal and professional philosophy, is the formulated "values- perspective" consistently displayed within Beck's analyses, assessments, and recommendations. Beck recommends, quite appropriately I believe, that we take as our starting-point with these two questions certain basic values inherent within our human nature and our human condition: "survival, happiness, friendship, selfrespect, fulfilment, a sense of meaning in life ... or, in a phrase, "human wellbeing' (or 'the good life')" (viii). Drawn from this broadly Aristotelian teleological premise is the view that the ultimate purpose of schooling is precisely to promote the values expressive of human well-being and, equally as important, to promote the equality of well-being within social institutions. Beck's consequent procedure throughout the book is to identify the sources of the scandal of schooling specifically as factors which limit and undermine such values within society, and to provide practical concrete suggestions for reform in light of a consideration of how such values can most effectively and efficiently be promoted within our practices of teaching, administration, and curriculum development. As developed out of the "values-perspective," the book's most fundamental recommendation is succinctly rendered in what must be seen as its very timely "manifesto": "The school can better play its distinctive part in achieving this goal if it greatly increases its emphasis on personal and social education. While not neglecting traditional 'basics' ... the school should give much more attention than at present to fields such as values, culture, religion, politics, economics and ecology" '(ix). Such a recommendation should be and is recognized by Beck as a basic point of contention today with large sectors of society strongly calling for a deeper concentration, in curricular content and scheduling, on those "life-skills" (i.e., basic literacy, mathematics, scientific literacy) which the student will be required and assumed to possess by a posttechnological society. It is a central and commendable objective of the book as a whole to show that the kinds of mastery and competence involved in social 
and political literacy cannot consistently be viewed as "frills" -- or worse, avoided completely in virtue of its "subjective," "ideological," character -once the "well-being" of individuals and society is acknowledged as what is really at stake here-and-now and for the foreseeable future. The tripartite division of the book clearly marks out the basic objectives of Beck's program and its justification.

In the Introduction and Part One ("Getting our Bearings"), Beck lays out the philosophical grounds of the "values-perspective" and goes on to articulate the components of "personal and social education" as objectives serving the underlying purpose of schooling. In recommending the kind of school best able to realize this purpose, Beck isolates factors which undermine the ideal of human well-being and its equality. Beck's overall approach is clearly displayed in his arguments here for a comprehensive form of schooling free from segregation according to socio-economic or ethnic background or scholastic achievement levels ("streaming" or "tracking") and one which operates with a common curriculum oriented neither to trade, nor professional, vocationalism. Separate chapters on the major interest groups (students, teachers, parents, society at large) illustrate how the values-perspective is able to incorporate and at times point out the limitations of various critical accounts of schooling developed by such writers as Holt, Kozol, Illich, Freire, Apple, Bowles and Gintis, and Giroux.

Part Two ("Specific Value Issues") devotes separate chapters to factors which discriminate against groups of students and sectors of society including racism, religious bias, sexism, and ethnic bias. Chapters on "Compulsion" and "Indoctrination" searchingly ask after the justifiability of imposed limits to freedom, and the possibility of a complete avoidance of non-critical and nonvoluntary components of schooling. Typically characteristic of these discussions is a sense for the right question, an awareness of the relevant literature, and a willingness to seek out the empirical evidence when called for by a position or recommendation.

The chapters within Part Three ("New Directions for Schools") offer a critical survey of existing programs in "Moral and Values Education", "Religious and Spiritual Education", and "Political and Global Education" together with a statement in each case of the specific positive contributions of such forms of education to the ideal of well-being. Specific proposals for ways of implementing these within the school are offered. Of particular interest here are: 1) an account of the inadequacy of a form of moral education which disengages itself from "non-moral" personal, social, political, economic, aesthetic, and ecological values; 2) a conception of a form of "spirituality" defined neither exclusively by "inferiority" nor necessarily by a belief in the supernatural or divine; and 3) an endorsement of forms of political commitment and activism with respect to major societal problems and global concerns which are typically excluded from the realm of schooling due to their controversial "non-objective" character.

This is an enlightening and useful book which makes a significant contribution to our understanding of the nature and role of values education within our schools. History has already given its message a touch of the prophetic.

Reviewed by Walter C. Okshevsky 